\title{
PHYCOREMEDIATION OF MALACHITE GREEN AND REDUCTION OF PHYSICO-CHEMICAL PARAMETERS FROM POLLUTED WATER USING Chlorella pyrenoidosa
}

\author{
J.Thirumagal $^{1}$, A.Panneerselvam ${ }^{2}$ \\ ${ }^{1}$ Research Scholar, Department of Zoology, Thiruvalluvar University, Vellore, Tamil Nadu, India \\ ${ }^{2}$ Associate Professor, Department of Zoology, Thiruvalluvar University, Vellore, Tamil Nadu, India
}

\begin{abstract}
Water is the elixir of life, a precious gift of nature to all the living species on earth. It is rapidly becoming a scare commodity in most parts of the world. Only $0.35 \%$ of the total availability of water found in lakes and wetlands and $0.01 \%$ in rivers and streams which are likely getting depleted due to the discharge of the effluents such as dyes simultaneously increases the water quality parameters. Malachite green is a common textile dye being discharged in lake water situated near textile industries. The phycoremediation method employs the use of algae, say, Chlorella pyrenoidosa which helps in decolorizing the water and due to its growth in the lake water, the physico-chemical parameters higher in the polluted water found to be reduced and water can be used for various purposes. The trails were made using Chlorella pyrenoidosa and Malachite green at different concentrations. The optimum concentration for the degradation of dye was completely done at the concentration $15 \mathrm{mg}$ confirming the decolorization capacity by Chlorella pyrenoidosa. The same experiment was performed with adjusting the pH at 6, 7 and 8 . Optimum $\mathrm{pH}$ for the dye degradation was found as $\mathrm{pH} 7$ at which all the concentrations Chlorella pyrenoidosa was able to degrade the dye with the decolourization capacity of above 95\%. The phyico-chemical parameters checked after the decolorization by Chlorella were found to be within the limits and thus Chlorella which is available in nature can be used in the decolorization of effluent water by eco-friendly method.
\end{abstract}

Keywords: Chlorella pyrenoidosa, Malachite Green, Phycoremediation, Physico-chemical parameters

\section{INTRODUCTION}

Water is an essential element for life. Water which has great solvent power, is constantly threatened to get polluted easily. Pollution in broad sense refers to any change causing imbalance in the natural quality of the environment through physical, chemical or biological processes. These industrial pollutants degrade ecosystem; pollute the water bodies, damage aquatic ecosystem, damage the soil fertility and soil subsystem. The effluent contains various inorganic and organic substances in different concentration may affect the nature and quality of Lake Water.

Freshwater comprises $3 \%$ of the total water on earth. Only a small percentage $(0.01 \%)$ of this freshwater is available for human use [1]. Unfortunately even this small proportion of freshwater is under immense stress due to rapid population growth, urbanization and unsustainable consumption of water in industry and agriculture.

\subsection{Role of Industries}

Industries that use large amounts of water for processing the products have the potential to pollute waterways through the discharge of their waste into streams and rivers, or by runoff and seepage of stored wastes into nearby water sources. The textile industry uses high volumes of water throughout its operations, from the washing of fibres to leaching, dyeing and washing of finished products. On average, approximately 200 litres of water are required to produce $1 \mathrm{~kg}$ of textiles [2]. The large volumes of wastewater generated contain a wide variety of chemicals. If not properly treated before being discharged into the environment, these chemicals can cause damage [3].

\subsection{Textile Dyes}

In textile industries, Malachite green (MG) is very commonly used dye. Malachite green is an organic compound that is used as a dyestuff and has emerged as a controversial agent in aquaculture [4]. Malachite green causes adverse effects to the human food chain by transforming in organisms from malachite green to leucomalachite green, accumulating in the tissues of exposed organisms and can easily get into the human food chain. Malachite green belongs to the group of triphenylmethane dyes as crystal violet which possess carcinogenic effects. MG is active against the oomycete Saprolegnia and infects fish eggs in commercial aquaculture. It is also active against some fungal species [5].

\subsection{Decolorization of Lake Water}

Biosorption is a technique used for the removal of nonbiodegradable pollutants from waters such as metals and dyes. A variety of biomaterials are known to bind these pollutants, including bacteria, fungi, algae, and industrial and agricultural wastes [6]. 


\subsubsection{Phycoremediation}

Phycoremediation is the application of macro or micro algae for the removal of biotransformation of pollutants including nutrients and xenobiotics from waste or polluted water and carbondioxide from waste air [7]. Industrial effluents can be conventionally treated using a variety of hazardous chemicals for $\mathrm{pH}$ correction, colour and odour removal whereas Algal technology avoids use of chemicals; it is highly economical and eco-friendly. The advantages of this technology are reduction of BOD, COD and less space requirement [8].

\subsubsection{Importance of Chlorella Pyrenoidosa}

Generally Textile dyes may be removed by biosorbents. A number of studies have focused on some microorganisms that are able to decolorize, biosorb or biodegrade dyes in wastewaters. Biosorption was described on microorganisms, including microalgae Cosmarium sp., Chlorella, Chlamydomonas, bacteria Kurthia sp., Citrobacter sp. and fungi Formessclerodermeus, Phanerochaete chrysosporium [9]. The Chlorella pyrenoidosa used as a biosorbent as the cell walls of Chlorella pyrenoidosa are made of amorphous mucilaginous material comprising of the nutrients such as polysaccharides, Lipids, proteins. These cellulosic materials consist of the binding sites such as hydroxyl, carbonyl and carboxyl groups which act as biosorbing sites with negative charges leading to the uptake and consumption of the dyes ultimately ends in decolourization of water [10].

\section{MATERIALS AND METHODS}

\subsection{Study Area}

The water samples were collected from Gudiyattam Lake, Gudiyattam, Vellore Dt., and Tamil nadu.

\subsection{Sample Collection}

The lake water samples collected from one location. The samples were collected in the pre-cleaned polythene bottles with necessary precautions.

\subsection{Water Analysis}

The $\mathrm{pH}$, temperatures, conductivity and total dissolved solids of the samples were noted. The samples were subjected to the physical and chemical tests such as hardness, total dissolved solids, Salinity and chlorides. Standard procedure involving volumetric was used for the experiment. Dissolved oxygen was fixed immediately after collection and then determined [11]. Nutrients (NH4+, NO3, and PO43) were determined by standard photometric method U.V visible spectrophotometer. Samples for BOD were incubated in laboratory for five days at $20^{\circ} \mathrm{C}$ [12].Turbidity was measured by Nephelometer using 0.02 NTU standards. Total hardness was estimated by the complex metric titration with standard EDTA solution using EriochromeBlack $\mathrm{T}$ as indicator. Whatmann filter papers were used for the determination of TSS and TDS methods. The results were compared to ICMR standards [13].

\subsection{Growth of Chlorella Pyrenoidosa in Lake Water}

\section{in Small Scale}

The lake water was supplemented with nutrients using the Chlorella pyrenoidosa's specific medium called Fog's medium; the Chlorella was able to adapt itself in Lake Water which was identified by the green color of the Chlorella pyrenoidosa growth. The growth of Chlorella pyrenoidosa was measured using UV Spectrophotometer at $680 \mathrm{~nm}$ for a period of 10 days by using different concentrations of Chlorella namely $2 \mathrm{ml}, 4 \mathrm{ml}, 6 \mathrm{ml}$ and 8 $\mathrm{ml}$ respectively to identify the maximum growth.

\subsection{Artificial Polluted Water Preparation}

The polluted lake water was artificially prepared by adding different concentrations of Malachite Green, a textile dye in order to check for the biodegradation of dye by the Chlorella pyrenoidosa of different concentrations. Thus the artificial polluted water is prepared and the experiment is continued further.

\subsection{Biodegradation of Dye by Algae}

Malachite green dye can be removed by biosorbent namely Chlorella pyrenoidosa which decolorizes, biosorb or biodegrade dyes in waters [14]. The use of Chlorella pyrenoidosa as biosorbent for the treatment of lake water will provide as a potential alternative to the conventional treatment

\subsubsection{Procedure:}

- $\quad$ The malachite green was equilibrated with $50 \mathrm{ml}$ of desired concentrations in water namely $5,10,15,20$, $25,30 \mathrm{mg}$ possessing 5, 10, 15, 20, 25, $30 \mathrm{ppm}$ were taken for the experiment.

- $\quad$ They were inoculated with Chlorella pyrenoidosa of various concentrations such as $2 \mathrm{ml}, 4 \mathrm{ml}, 6 \mathrm{ml}$ and $8 \mathrm{ml}$ respectively.

- $\quad$ The dye solutions for a predetermined period of time at a constant temperature of $37 \pm 20^{\circ} \mathrm{C}$ on a rotary shaker $(170 \mathrm{rpm})$ for equilibrium adsorption studies.

- After the equilibration, separation was done by filtration using Whatmann No.41 filter paper.

- The first $10 \mathrm{ml}$ of filtrate was discarded and the remaining filtrate was analysed for the dye concentration.

- $\quad$ The absorbance was measured for a period of 7 days in UV Spectrophotometer.

- $\quad$ Then, the same dye solution of all the concentrations were centrifuged at $5000 \mathrm{rpm}$ for $5 \mathrm{~min}$ and the supernatant was taken for the measurement of absorbance at $619 \mathrm{~nm}$ inorder to check the degradation of dye by Chlorella pyrenoidosa.

- After performing the experiment, the dye solutions were kept in the green house for the further growth of Chlorella pyrenoidosa.

- $\quad$ This experiment is repeated for a period of 7 days. 


\subsection{2 pH Variation Studies}

The same experiment was repeated with the adjustment of various $\mathrm{pH}$ with dilute $\mathrm{HCl}$ or $\mathrm{NaOH}$ solutions [15]

\subsubsection{Effect of $\mathrm{pH}$}

Algae draw carbon dioxide from the water to utilize during photosynthesis, promoting cell growth [16]. Removal of carbon dioxide from the water raises the $\mathrm{pH}$ levels, as a result of the reduction in carbonate and bicarbonate levels of water, since they are used to replenish the lost carbon dioxide. Depletion of inorganic carbon from water by algae results in high $\mathrm{pH}$ levels, as evidenced by the rise in $\mathrm{pH}$ levels of natural waters, which can go up to 10 or beyond in the presence of algae [17]. The rise of water $\mathrm{pH}$ also causes ionization of ammonia which is detrimental to aquatic life.

\section{Experiment}

- The malachite green was equilibrated with $50 \mathrm{ml}$ of desired concentrations of water namely $5,10,15$, $20,25,30 \mathrm{mg}$ possessing $5,10,15,20,25,30 \mathrm{ppm}$ were taken for the experiment.

- $\quad$ They were inoculated with Chlorella pyrenoidosa of various concentrations of 2, 4, 6, $8 \mathrm{ml}$ respectively.

- The dye solutions for a predetermined period of time at a constant temperature of $37 \pm 20^{\circ} \mathrm{C}$ on a rotary shaker $(170 \mathrm{rpm})$ for equilibrium adsorption studies.

- After the equilibration, separation was done by filtration using Whatmann No.41 filter paper.

- The first $10 \mathrm{ml}$ of filtrate was discarded and the remaining filtrate was analysed for the dye concentration.

- $\quad$ The absorbance was measured for a period of 7 days in UV Spectrophotometer.

- Dye solutions were centrifuged and the absorbance was read at $619 \mathrm{~nm}$ to check the degradation of dye.

- Then, the dye solutions of all the six concentrations were adjusted with the $\mathrm{pH} 6, \mathrm{pH} 7$ and $\mathrm{pH} 8$ in order to check the best $\mathrm{pH}$ for the degradation of dye.

- The same solutions of all the six concentrations were centrifuged at $5000 \mathrm{rpm}$ for $5 \mathrm{~min}$ and the supernatant was taken for the measurement of absorbance at $619 \mathrm{~nm}$ in order to check the degradation of dye by Chlorella pyrenoidosa.

- After performing the experiment, the dye solutions were kept in the green house for the further growth of Chlorella pyrenoidosa.

- $\quad$ This experiment is repeated for a period of 7 days.

\section{Decolourization Calculation}

$\%$ Decolorization =Initial absorbance-Final absorbance 100 Initial absorbance

\section{RESULTS AND DISCUSSION}

Table -1: Analysis of Physiochemical parameters in lake water of Gudiyattam Lake

\begin{tabular}{|l|l|l|l|}
\hline S.No & Parameters & $\begin{array}{l}\text { Drinking } \\
\text { water } \\
\text { standard }\end{array}$ & $\begin{array}{l}\text { Effluent } \\
\text { contaminated } \\
\text { lake water }\end{array}$ \\
\hline 1. & Colour & clear & $\begin{array}{l}\text { Green-Straw } \\
\text { yellow }\end{array}$ \\
\hline 2. & Odour & unobjectionable & objectionable \\
\hline 3. & PH & $6.8-8.2$ & 7.45 \\
\hline 4. & BOD & 40 & 106 \\
\hline 5. & COD & 230 & 296 \\
\hline 6. & Alkalinity & 190 & 460 \\
\hline 7. & Hardness & 280 & 480 \\
\hline 8. & Chloride & 230 & 310 \\
\hline 9. & Nitrate & 40 & 45 \\
\hline 10. & Calcium & 70 & 190 \\
\hline 11. & Magnesium & 30 & 120 \\
\hline
\end{tabular}

The colour of the effluent treated water was greenish and brownish. The Sample collected from the effluent discharged water storage lake was found to have unobjectionable odour. The $\mathrm{pH}$ of the lake water sample is 7.45. The $\mathrm{pH}$ value of the lake water sample is under the normal range when compared with the drinking water standard. The lake water has high BOD level of $106 \mathrm{mg} / \mathrm{l}$. This shows the seepage of organic and inorganic waste materials from the effluent into nearby lake water [18]. Increased level of COD in sample of $296 \mathrm{mg} / \mathrm{l}$ shows the higher level of contamination. The total alkalinity was noted that $460 \mathrm{mg} / \mathrm{l}$ indicating the presence of bicarbonates, carbonates and hydroxides [19]. The total hardness is $480 \mathrm{mg} / \mathrm{l}$ indicating the increased amounts of calcium and magnesium in the water. The chloride content of the lake water showed a high level of $310 \mathrm{mg} / \mathrm{l}$ which is very salty. The total concentration of nitrate is $45 \mathrm{mg} / \mathrm{l}$ which is more or less equal to standard. The calcium concentration of contaminated lake water is $190 \mathrm{mg} / \mathrm{l}$, the level of calcium is found to be very high which contributes to the hardness of water [20]. The level of magnesium in the contaminated lake water is $120 \mathrm{mg} / \mathrm{l}$ indicating the contamination of lake water. From the above analysis, it is clearly understood that the Lake water is unfit for any purpose.

Table -2: Growth of Algae in Lake Water

\begin{tabular}{|l|l|l|l|l|}
\hline DAYS & $\mathbf{2 ~ m l}$ & $\mathbf{4 ~ m l}$ & $\mathbf{6 ~ m l}$ & $\mathbf{8 ~ m l}$ \\
\hline 0 & 0.0690 & 0.1048 & 0.1060 & 0.1457 \\
\hline 1 & 0.0609 & 0.0868 & 0.0884 & 0.1155 \\
\hline 2 & 0.0627 & 0.1094 & 0.1064 & 0.1187 \\
\hline 3 & 0.0689 & 0.1251 & 0.1721 & 0.2023 \\
\hline \multicolumn{5}{|l|}{} \\
\hline 5 & 0.0827 & 0.1498 & 0.2540 & 0.3385 \\
\hline 6 & 0.0928 & 0.1568 & 0.2637 & 0.3929 \\
\hline 7 & 0.1135 & 0.1741 & 0.2788 & 0.4220 \\
\hline 8 & 0.1226 & 0.1963 & 0.2911 & 0.4931 \\
\hline 9 & 0.1299 & 0.2009 & 0.3017 & 0.5507 \\
\hline 10 & 0.1378 & 0.2169 & 0.3198 & 0.7789 \\
\hline
\end{tabular}


The Chlorella in the lake water was very well adapted to it and efficiently grown in the period of 10 days. $2 \mathrm{ml}$ Chlorella concentration was very much effective and was sufficient for its rapid growth though the growth was observed in all other concentrations such as $4 \mathrm{ml}, 6 \mathrm{ml}$ and 8 $\mathrm{ml}$.

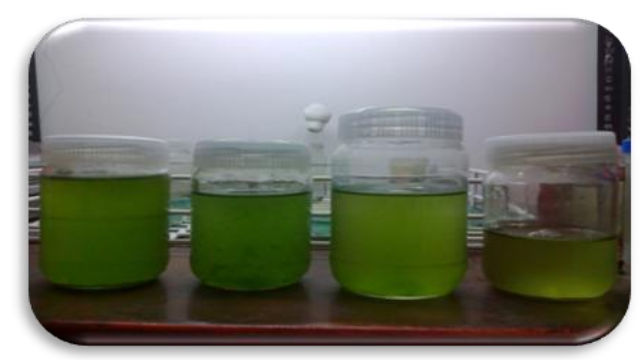

Fig -1: Growth of Chlorella in Lake water

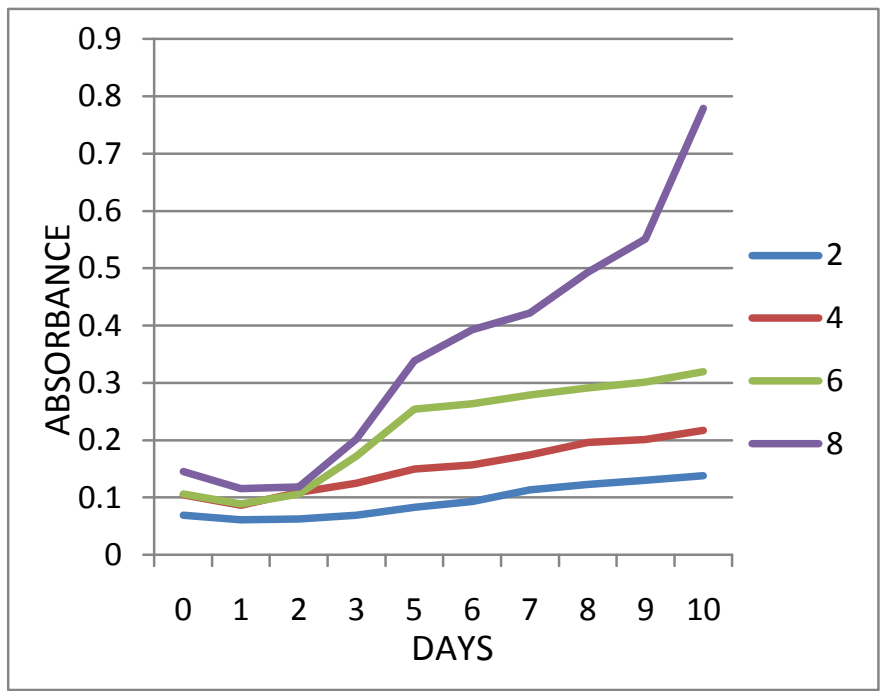

Chart -1: Graph Showing the Growth of Chlorella at Different Concentrations in Lake Water

Table -3: Growth of Algae in Lake Water

\begin{tabular}{|l|l|l|}
\hline S.No & Parameters & $\begin{array}{l}\text { Effluent } \\
\text { contaminated lake } \\
\text { water }\end{array}$ \\
\hline 1 & PH & 7.36 \\
\hline 2 & BOD & 41.2 \\
\hline 3 & COD & 227 \\
\hline 4 & Alkalinity & 181 \\
\hline 5 & Hardness & 286 \\
\hline 6 & Chloride & 230.6 \\
\hline 7 & Nitrate & 37 \\
\hline 8 & Calcium & 71.3 \\
\hline 9 & Magnesium & 21 \\
\hline
\end{tabular}

The same physico parameters were analysed once the Chlorella attained its growth in the water after about 10 days. It was found that the Chlorella consumed all the nutrients from water and the parameters were absolutely equal to the standard which made the water free from the effluents.

\section{Experiment without pH:}

\begin{tabular}{|l|l|l|l|l|}
\hline DAYS & $\mathbf{2}$ ml & $\mathbf{4 ~ m l}$ & $\mathbf{6 ~ m l}$ & $\mathbf{8}$ ml \\
\hline 0 & 0.0425 & 0.0864 & 0.0873 & 0.1141 \\
\hline 1 & 0.052 & 0.0682 & 0.0737 & 0.0832 \\
\hline 2 & 0.0281 & 0.0438 & 0.0495 & 0.0464 \\
\hline 3 & 0.019 & 0.0178 & 0.0185 & 0.024 \\
\hline SUNDAY \\
\hline 5 & 0.0042 & 0.0057 & 0.0042 & 0.0062 \\
\hline 6 & 0.0009 & 0.0008 & 0.005 & 0 \\
\hline
\end{tabular}

\section{\% Decolourization:}

$2 \mathrm{ml}=97.8 \%$

$4 \mathrm{ml}=99 \%$

$6 \mathrm{ml}=94.2 \%$

$8 \mathrm{ml}=99.2 \%$

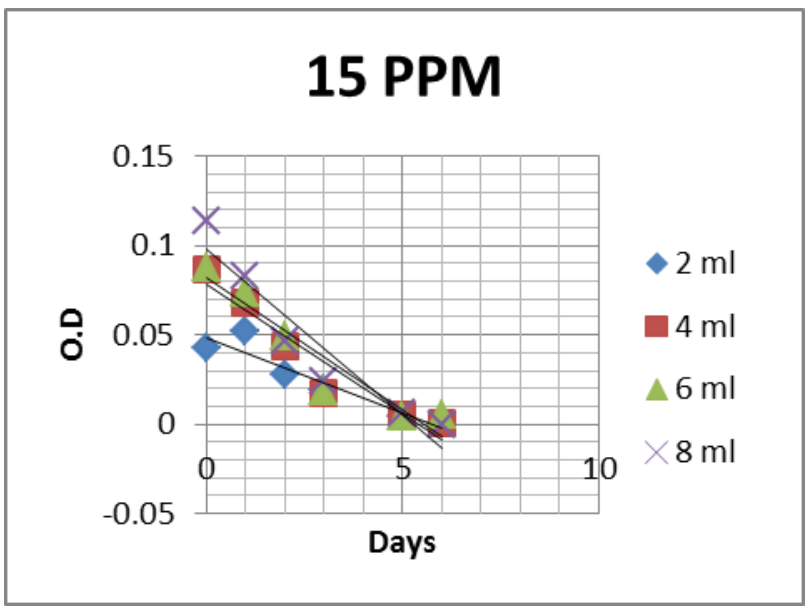

Chart -2: Graph Showing the Degradation of Dye at 15 ppm

The degradation was very efficient with the $15 \mathrm{mg} / \mathrm{ppm}$ concentration of Malachite green. The Biodegradation was absolutely seen in all the concentrations but the efficiency of decolorization is high in $15 \mathrm{ppm}$.

\section{Experiment with pH:}

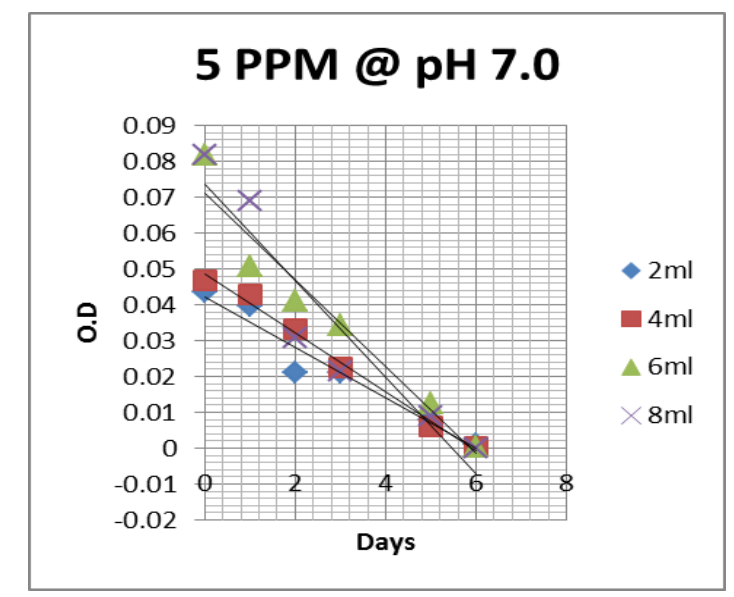

\section{$\%$ Decolourization}

$2 \mathrm{ml}=97.2 \%$

$4 \mathrm{ml}=99.6 \%$

$6 \mathrm{ml}=99.3 \%$

$8 \mathrm{ml}=99 \%$ 


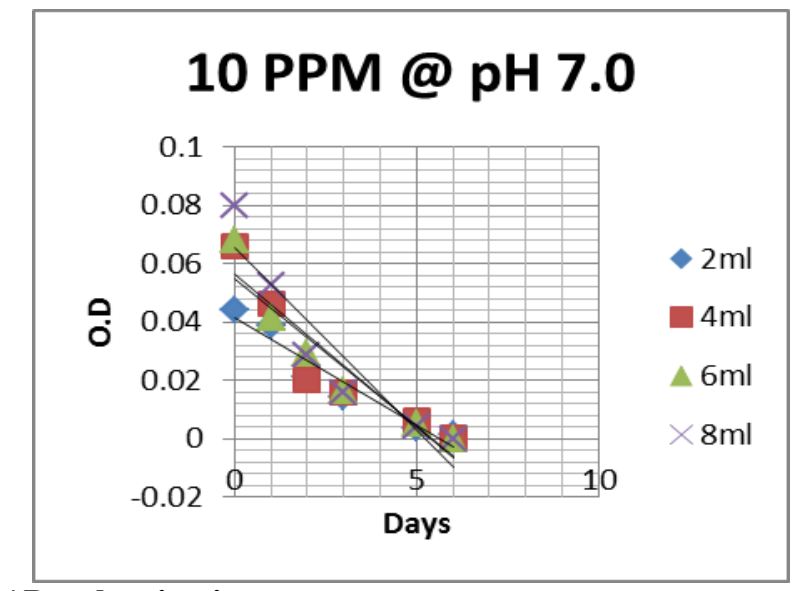

\section{\% Decolourization:}

$2 \mathrm{ml}=96.6 \%$

$4 \mathrm{ml}=99.5 \%$

$6 \mathrm{ml}=97.5 \%$

$8 \mathrm{ml}=98.6 \%$

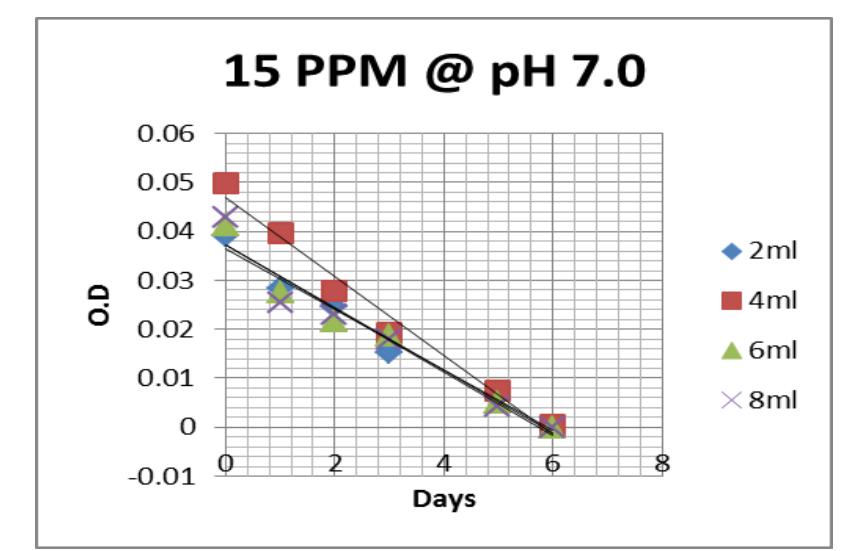

\section{\% Decolourization:}

$2 \mathrm{ml}=94.1 \%$

$4 \mathrm{ml}=98.9 \%$

$6 \mathrm{ml}=98 \%$

$8 \mathrm{ml}=97.2 \%$

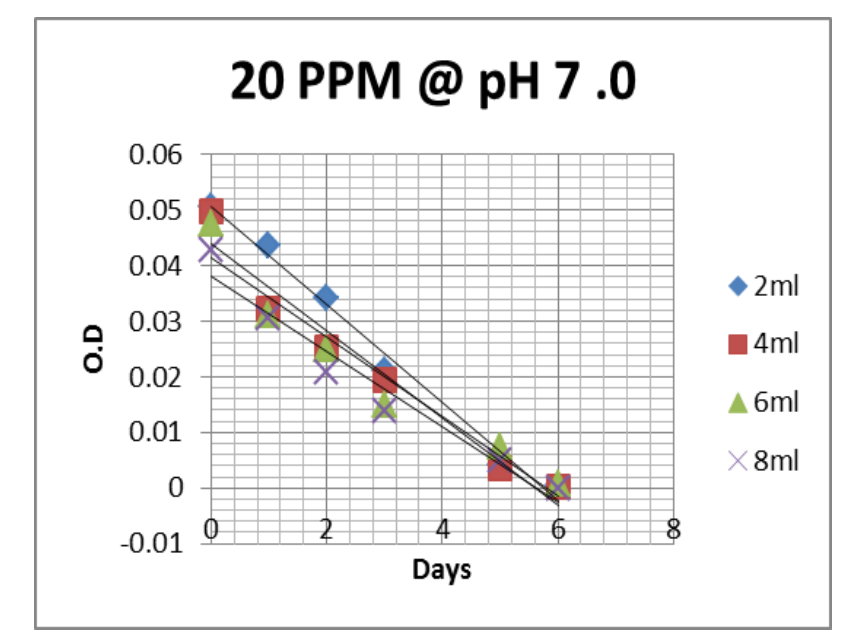

\section{\% Decolourization}

$2 \mathrm{ml}=99.2 \%$

$4 \mathrm{ml}=99.7 \%$

$6 \mathrm{ml}=98.3 \%$

$8 \mathrm{ml}=98.3 \%$

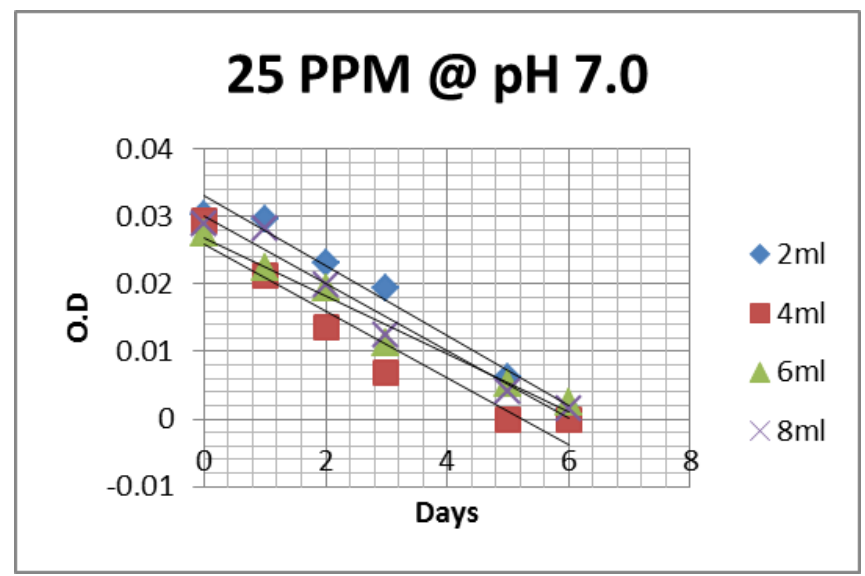

$$
\begin{aligned}
& 2 \mathrm{ml}=96 \% \\
& 4 \mathrm{ml}=96.5 \% \\
& 6 \mathrm{ml}=91.3 \% \\
& 8 \mathrm{ml}=97.4 \%
\end{aligned}
$$$$
\text { \% Decolourization: }
$$

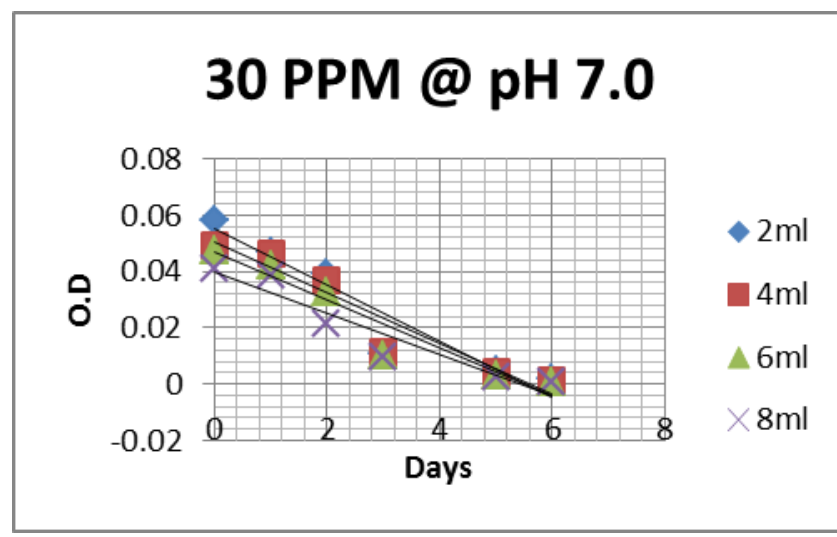

\section{\% Decolourization:}

$2 \mathrm{ml}=97.2 \%$

$4 \mathrm{ml}=97.1 \%$

$6 \mathrm{ml}=98.1 \%$

$8 \mathrm{ml}=98.5 \%$

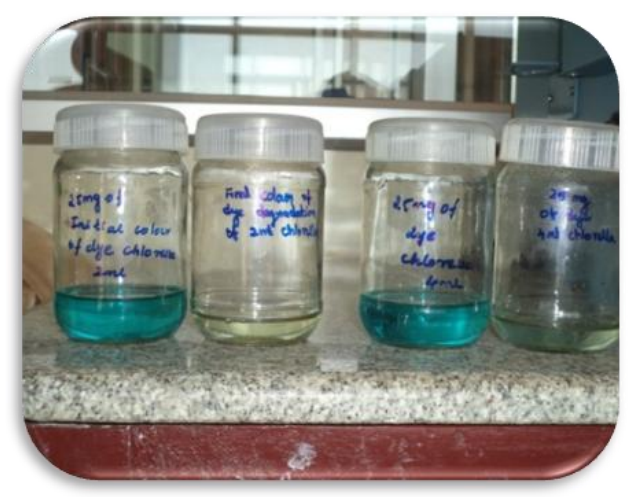

(a) 


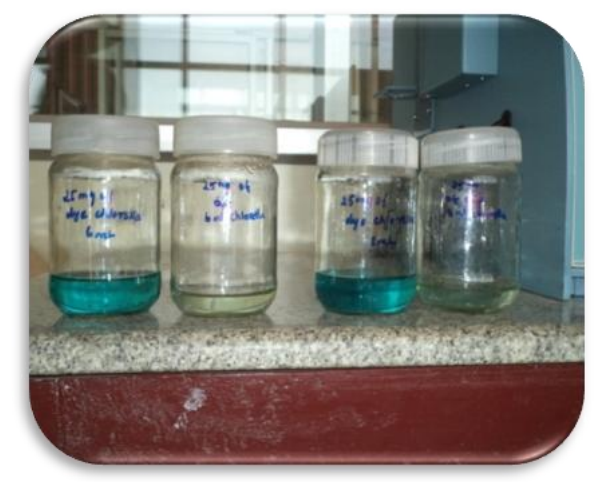

(b)

Fig-2 (a): Initial and final color of the $2 \mathrm{ml}$ and $4 \mathrm{ml}$ solutions at pH 7 (b): Initial and Final color of the $6 \mathrm{ml}$ and $8 \mathrm{ml}$ solutions at $\mathrm{pH} 7$

The degradation of dye was observed at all the concentrations and at all $\mathrm{pH}$. The optimum $\mathrm{pH}$ for the dye degradation was found as $\mathrm{pH} 7$ at which all the concentrations Chlorella pyrenoidosa was able to degrade the dye. $\mathrm{pH} 8$ was equally good as $\mathrm{pH} 7$ but slower degradation was observed at $\mathrm{pH} 6$.

\section{CONCLUSION}

The lake water is deteriorated in Vellore as all the parameters such as TDS, chloride, hardness and salinity is found high. By Phycoremediation method, it was found that the Chlorella pyrenoidosa degraded the dye efficiently day by day once it reached its growth in the dye. Though, the algae grown at all the concentrations, the optimum concentration for the degradation of dye was completely done at the concentrations $15 \mathrm{mg}$ for the set of experiment without $\mathrm{pH}$. The optimum $\mathrm{pH}$ for the dye degradation was found as $\mathrm{pH} 7$ at which all the concentrations Chlorella pyrenoidosa was able to degrade the dye and the decolorization was observed above 95\%. It was concluded that the removal of malachite green was very effective from the aqueous solution by Chlorella pyrenoidosa which has the ability to degrade the dye and helps in the reduction of the BOD, COD parameters and turns up the effluent water to useful water.

\section{ACKNOWLEDMENTS}

The authors record their sincere thanks to Dr. V. Palani, Managing Director and Mrs. Manasa Satheesh, Director of Genewin Biotech, Hosur for providing Technical support and necessary laboratory facilities to carry out this work in their DBT certified laboratory.

\section{REFERENCES}

[1]. D. Hinrichsen, H. Tacio, "The coming freshwater crisis is already here. The linkages between population and water", Washington, DC: Woodrow Wilson International Center for Scholars, 2002.
[2]. S.R. Little Flower, "Environmental pollution-Especially air pollution- and public helath", Au J. T. 10(1), pp. 29-37, 2006.

[3]. K. Usharani, K. Umarani, P.M. Ayyasamy, K. Shanthi, P. Lakshmana perumalsamy, "Physicochemicaland bacteriological characteristics of Noyyal river and ground water quality of Perur, India", J Appl.Sci. Environ. Manage. 14(2), pp. 29-35, 2010.

[4]. J. Das, B.C. Acharya, "Hydrology and assessment of lotic water quality in Cuttack city,India", Water Air Soil Pollut. 150, pp. 163-175, 2003.

[5]. K. Pandey Sandeep, S. Tiwari, "Physico-chemical analysis of ground water of selected area of Ghazipur city-A case study", Nat. Sci.7(1), 2009.

[6]. S.J. Altman, R.R. Parizek, "Dilution of nonpoint source nitrate in ground water", J. Environ. Qualit. 24, pp. 707-717, 1995.

[7]. A.S. Adekunle, "Effects of Industrial Effluent on Quality of Well Water within Asa Dam Industrial Estate, Ilorin, Nigeria", Nat. Sci.7(1), 2009.

[8]. A Jinwal, S. Dixit, "Pre and post monsoon variation in physio-chemical characteristic in groundwater quality in Bhopal, India”, Asian J. Exp. Sci. 22 (3), 2008.

[9]. M. RaoSudhkar, P. Mamatha, "Water quality in sustainable water management”, Curr.Sci. 87 (7), 2004.

[10]. B.N. Mahanta, B.C. Sarkar, G. Singh, K. Saikia, P.R. Paull, "Multivariate statistical modeling and indexing of ground water quality in and around Jharia coal fields", 2004. [11]. B.B. Singh, "Pollution status of Tapti River at Gorakpur", J. Environ. Pollut. 2(3), pp. 117 - 120, 1995.

[12]. Gupta, "Acute toxicity to as estuarine toleost of mixtures of $\mathrm{Cd}, \mathrm{Cu}$, and $\mathrm{Zn}$ salts", 1984

[13]. APHA, "Standard Methods for the Examination of Water and Wastewater", APHAAWWA-WPCF, 1998.

[14]. WHO, "Recommendations, Water and Sanitation. Guidelines for Drinking Water Quality", 1, 1984.

[15]. Abdullah Al-Fawwaz, Jacob H Jacob, "Removal of Methylene Blue and Malachite green from aqueous solutions by Chlorella and Chlamydomaonas species isolated from a thermal spring environment", Int. J. Integr. Biol. 12 (1), pp. 36 - 40, 2011.

[16]. Maulin P Shah, "Microbial Degradation of Textile Dye (Remazol Black B) by Bacillus spp", J. Appl. Environ. Microbiol. 1(1), pp. 6-11, 2013.

[17]. Ratna, B.S. Padhi, "Pollution due to synthetic dyes toxicity \& carcinogenicity studies and remediation", Int. J. Environ. Sci. 3(3), 2012.

[18]. E. Sudova, J. Machova, Z. Svobodova, T. Vesely, "Negative effects of malachite green and possibilities of its replacement in the treatment of fish eggs and fish:a review", Vet. Med. 52 (12), pp. 527-539, 2007.

[19]. S. Sivamani , C. Parvathi , C. Prakash and C. V. Koushik, "Removal of malachite green from its Aqueous solution by Pithophora sp.”, Adv. Biotech. 32, 2009

[20]. Mohamed Saad Abd-El-Kareem, Hala Mohamed Taha, "Decolorization of Malachite Green and Methylene Blue by Two Microalgal Species”, Int. J. Chem. Environ. Engg. 3(5), 2012. 


\section{BIOGRAPHIES}

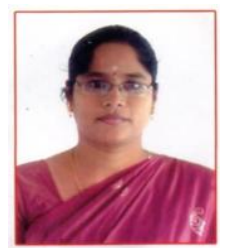

Degree Earned: Master of Science in

Biochemistry, Master of Philosophy in

Biochemistry, Pursuing Doctor of

Philosophy.

Current Position: Research Scholar in Thiruvalluvar University, Vellore.

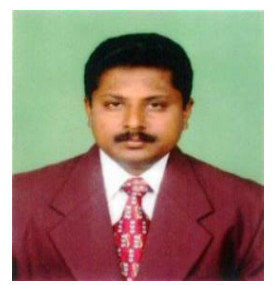

Degree Earned: Master of Science, Master of Philosophy, Ph.D.

Specialization: Industrial Biotechnology \& Environmental Biology

Membership: Indian Society of Invertebrate Reproduction, Indian Society of Toxicology, Biochemical Society, Society for Environment and Development.

No of Publications: 12

Work Experience: Working as Associate Professor in Thiruvalluvar University, Vellore. 